\title{
“Kötülüğün Sıradanlığı”: Aleksandr Soljenitsın’ın Sovyet çalışma kampı izlenimlerini Hannah Arendt'in kavramlarıla okumak
}

Duygu ÖZAKIN'

\begin{abstract}
APA: Özakın, D. (2019). “Kötülüğün Sıradanlığı”: Aleksandr Soljenitsın’ın Sovyet çalışma kampı izlenimlerini Hannah Arendt'in kavramlarıyla okumak. RumeliDE Dil ve Edebiyat Arașturmalar Dergisi, (15), 431-468. DOI: 10.29000/rumelide.580703
\end{abstract}

$\ddot{\mathbf{O} z}$

20. yüzyll dünya siyasi tarihinde toplama ve çalışma kampları, rejimle bireyin çatıştığı ya da çatışma tehlikesinin varsayıldı $\breve{1}$ dönemlerde kurularak toplumsal tasfiyelerin aracı haline getirilmiş olan sistematik cezalandırma mekânlarıdır. Kamp yaşamının kıskacında insan, toplumsal konumundan koparılmış olarak, “çıplak hayat”la; salt biyolojik ihtiyaçları doğrultusunda bir bağ kurar. Bu bağ, kamplardan kurtulmayı başaran Primo Levi, Varlam Şalamov, Yevgeniya Ginzburg gibi edebiyatçıların anılarının yanı sıra, biyolojik yaşamın politikanın ufkuna dâhil edildiği kırılma noktalarını soruşturan Hannah Arendt gibi düşünürlerin de çalışmalarına konu olmuştur. Bu çalışma, 1970 yılında Nobel Edebiyat Ödülü’nü kazanan Rus yazar Aleksandr Soljenitsın’ın, Gulag olarak adlandırılan Sovyet ıslah ve zorunlu çalışma kamplarında bir mahkûmun tek günlük hikâyesini anlattığı “İvan Denisoviç’in Bir Günü” adlı otobiyografik eserini, 20. yüzyılın etkin düşünürlerinden Hannah Arendt’in toplama kampları ve totalitarizmin kaynaklarına ilişkin çıarımlarını kılavuz edinerek incelemeyi amaçlar. Bu çalışmada, kamp düzeneğini yaratan tarihi koşullar ve sistemin kurucusu olan siyasal aktörlerin eylemleri, Arendt’in "kötülüğün sıradanlığı" anlayışından yola çıkılarak çözümlenmiştir. Böylelikle katı kamp uygulamalarının, yaşamı öncelikle bedensel gereksinimleri giderme mücadelesine dönüştürerek, mahkûmları kendilerine yabancılaştırması ve bu olumsuz tecrübenin Soljenitsın'ın eserine yansıması üzerinde durulur.

Anahtar kelimeler: Arendt, Soljenitsın, beden politikaları, kamp, Gulag.

\section{“The Banality of Evil": Reading Alexander Solzhenitsyn's Impressions of Soviet labor camps through Hannah Arendt's concepts}

\begin{abstract}
Concentration and labor camps are spaces of systematic punishment that have become the means of social liquidation in 2oth century political history of the world. They are founded where the individual conflicts with the regime or the danger of conflict is assumed. In the predicament of camp life, human beings, detached from their social position establish a tie with their "bare life", in other words their purely biological needs. This connection takes place in the memoirs of authors such as Primo Levi, Varlam Shalamov, Eugenia Ginzburg, who were liberated from concentration camps. This tie has also been the subject of philosphers such as Hannah Arendt, who investigated the breaking points at which biological life is incorporated into the horizon of politics. This study aims to examine Russian writer Aleksandr Solzhenitsyn's (who won the Nobel Prize for Literature in 1970) autobiographical novel "One Day in the Life of Ivan Denisovich" referring to one of the most influential philosophers of the 2oth century Hannah Arendt's interpretations of concentration camps and the sources of
\end{abstract}


“The Banality of Evil”: Reading Alexander Solzhenitsyn's Impressions of Soviet labor camps through Hannah Arendt's concepts / D. Özakın (p. 431-449)

\begin{abstract}
totalitarianism. Solzhenitsyn's novel tells the one-day story of an inmate in the Soviet corrective labor camps called Gulag. The study tries to analyze the historical conditions that created the camp organization and the actions of the political actors who are the founder of the system through Arendt's conceptualization "the banality of evil". Thus, it focuses on compelling camp practices, transforming life into a struggle for purely bodily needs alienating prisoners from themselves, and reflections of this negative experience inside the novel.
\end{abstract}

Keywords: Arendt, Solzhenitsyn, politics of the body, camp, Gulag.

\title{
Giriş
}

İngiliz tarihçi ve yazar Eric Hobsbawm, 20. yüzyllı "aşırılıklar çağı" (the age of extremes) olarak tanımlar. Savaşlar, devrimler ve bu süreçlerin istenmeyen birer sonucu olarak yaşanan insan hakları ihlalleri, geçtiğimiz asrın siyasi arenasında belirleyici rol oynamıştır. Hobsbawm, "Aşırılıklar Çağı: Kısa 20. Yüzyıl” adını verdiği çalışmasının sınırlarını, I. Dünya Savaşı’nın başladığı 1914 yllından Sovyetler Birliği’nin dağıldığı 1991 yılına dek çizer. Hobsbawm'a göre, 20. yüzyılın temel deneyimlerinin belirlendiği dünya, 1980'lerin sonunda parçalanmıştır; bu sürecin başlangıcı ise 1917 Rus Devrimi ile biçimlenen dünyadır (Hobsbawm, 1996, s.16-17). Birliğin temellerinin 1917 Ekim Devrimi sayesinde atıldığı dikkate alındığında, "aşırılıklar çağı"nın önemli aktörlerinden birinin, Sovyetler Birliği olduğu görülür. Tarihçi Moshe Lewin’in tabiriyle, 20. yüzyll "Sovyet yüzyll”" olmuştur (Lewin, 2016, s.7) ve birlik, bilhassa Stalin diktatörlüğü döneminde, sözü edilen insan hakları ihlâlleri konusunda da istenmeyen tecrübelerin yaşandığı çalkantılı bir siyasal sistemin parçasına dönüşmüştür.

Bu çalışmada "aşırılıklar"ın bir simgesi olarak, zorunlu-çalıştırma ya da imha etme amacıyla, sistem karşıtı olan (veya olduğu iddia edilen) bireylerin toplandığı, niteliklerine göre "toplama kampı", "çalışma kampı", "imha kampı" gibi adlarla anılan ıslah mekânlarının Sovyetler Birliği’ndeki bir örneği olan "Gulag”2, kendisi de kamp cezasına çarptırılmış olan Rus yazar Aleksandr Soljenitsın’ın (1918-2008) "İvan Denisoviç’in Bir Günü” (Odin den’ İvana Denisoviça) adlı eseri çerçevesinde ele alınır.

Gulag çalıştırma kamplarının kuruluşunda, rejim karşıtlarını cezalandırmanın yanı sıra; "cezahların bedava işgücünü sistemli bir şekilde kullanarak, Sovyet ekonomisinin gelişmesine katkı sağlama" (Khairmukhanmedov, 2007, s.155) amacı güdüldüğü görülmektedir. 18. yüzyıldan itibaren, sürgün cezası alanların "ekonomik gelişmeye ve ücra bölgelerin kullanıma açllmasına katkı sağlaması amacıyla zorunlu çalışmaya" yollandıklarını belirten Gürsoy (2018, s.397), kampların "çalş̧ma kampları, ceza kampları, suçlu ve siyasi kampları, kadın kampları, çocuk kampları, geçiş kampları" olarak çeşitlilik gösterdiğini vurgular (Gürsoy, 2018, s.399). "F. M. Dostoyevski'nin Ölüler Evinden Anılar ve A. İ. Soljenitsın’ın İvan Denisoviç’in Bir Günü Adlı Eserlerinde Gerçekçilik” adlı çalışmasında Ceylan, "değişen yönetim şekilleriyle doğru orantıl olarak ceza sistemleri veya isimlerinin de şekil değiştirmiş olduğunu; Dostoyevski döneminde 'kürek mahkumiyeti’ (katorga) söz konusuyken, Soljenitsin döneminde kamp' (lager) sisteminin bulunduğunu”' (Ceylan, 2015, s.81) ifade eder.

Gulag sistemi, Rus tarihinde 1930'lardan önce benzerlerine rastlanan cezalandırma sistemlerinin, 20. yüzyıl anlayışılla yeniden şekillenmiş halidir. Sovyet kampları sistemini tüm özellikleriyle kaleme alan tarihçi Anne Applebaum, Solovki esir kampının, mahkumların hafızalarına Gulag'ın ilk kampı olarak kazındığını ifade eder. "Araştırmacılar, o zamana kadar birçok cezaevinin ve kampın zaten faaliyette bulunduğunu belirtmiş olsalar da Solovki, şüphesiz yalnızca eski mahkûmlarn değil, aynı zamanda

2 Islah-Çalışma Kampları ve Kolonileri Genel İdaresi (Gulag: Glavnoye upravleniye ispravitel'no-trudovıh lagerey i koloniy). 
Sovyet 'organlarında' görevli olanlarn anılarında da önemli bir yer teşkil etmiştir” (Applebaum, 2006, s.53). Zira, mahkûmların emeğinden gelir elde etmenin öğrenildiği ilk kamp Solovki olmuştur. Bu bilgi Sovyet ekonomisinin gelişimi için ihtiyaç duyulan insan gücü probleminin çözümü için kullanılmıştır ve 1930'larda sistematik hale gelecek Gulag'ın temeli, 1920'lerde Solovki sayesinde atılmıştır.

Stalin'in 1928 yllının sonlarına doğru çifte kolektivizasyon ve zorunlu sanayileşme politikalarıyla Sovyet toplumunu temelden değiştirme kararı, ülkenin milyonlarca tarım ve sanayi işçisini büyük ölçüde etkilemiştir. Bu kararla beraber Sovyet işgücü piyasası iki ana sektörle şekillenecektir: Bir yanda fabrikalardaki sivil-serbest işgücü; öte yanda, özgür olmayan zorunlu emekçilerin, Gulag olarak bilinen kamplar ve yerleşim zinciri aracıllğıyla seferber edilen işgücü (Kragh, 2014, s.43).

20. yüzyılın ıslah-çalışma kampı sistemini önceki örneklerinden daha acımasız kılan, yaşamın, aklın önderliğinde yeniden tasarlanabileceğine ve bu düzenin daha adilane olacağına duyulan inancın yerleşmiş olduğu bir çağda ortaya çıkmasıdır. Rasyonalizm adına, tekdüze ve duygulardan arındırılmış bir toplumsal işleyiş ve bu işleyişin yeni yasalarla teminat altına alınması, kamp gerçeğinin bir insanlık ayıbı olarak simgeleşmesiyle sonuçlanmıştır. Genç devletlerin, aklın ve bilimin önderliğinde, gelişmiş bir sanayiyle toplumsal ilerlemenin zirvesine eriştiklerini iddia ettikleri bir dönemde, insanlık suçlarının en trajikleri işlenmekte ve bu modern devlet düzeninin bir gerekliliği olarak "sıradan" hale getirilmektedir.

\section{Kuram: Hannah Arendt'in kötülük problemine yaklaşımı}

Fransız düşünür Michel Foucault’nun (1926-1984) nüfusun bedensel denetimi konusunda yaptı̆̆g geniş ufuklu çalışmaları, beden merkezli tartışmaları çok çeşitli perspektiflerden ele almaktadır. Ancak İtalyan düşünür Giorgio Agamben, Foucault'nun kapsamındaki önemli bir gediğe işaret etmektedir: Foucault'nun, kendisinden evvel bu konuya eğilen Hannah Arendt'in çalışmalarına değinmediğini; öte yandan, kamp gibi bedensel denetimin ve cezalandırmanın böylesine görünür hale getirildiği, neredeyse distopik bir uzam üzerine söz söylemediğini; Foucault'nun "modern biyosiyasetin örnek mekânlar olarak toplama kampları” üzerinde hiç durmadığını ifade eder (Agamben, 2017, s.12).

Agamben'in çalışmalarına işaret ettiği Hannah Arendt (1906-1975) "Totalitarizmin Kaynakları" (1951), "İnsanlık Durumu" (1958) ve "Kötülüğün Sıradanlığı" (1963) gibi yapıtları etrafında tartışılan, siyaset felsefesi literatürüne kattığı kavramlarla adından söz ettiren bir kadın düşünürdür. "Kötülüğün Sıradanlığı"nı, Yahudi soykırımının önemli aktörlerinden biri olarak kabul edilen ve toplama kamplarının düzeninden ve Yahudilerin bu merkezlere taşınmasından sorumlu tutulan Alman subay Adolf Eichmann'ın 1960 yılında Kudüs'te görülen davasındaki gözlemleri ve notları sonucunda derlemiş ve The New Yorker muhabiri olarak bunları kamuoyu ile paylaşmıştır.

Düşünürün izlenimlerinden edinilen bilgilere göre Nazi Almanyası'nda Yahudilerin toplanması ve kamplara yerleştirilmesinden sorumlu olan Eichmann, dava süresince suçlamaları reddetmiştir. Arendt'e göre Eichmann, esasında radikal bir Yahudi düşmanı değildir (Arendt, 2009, s.32). Ailesinde, arkadaş çevresinde Yahudi yakınları bulunan ve onlara karşı özellikle nefret beslemeyen sıradan bir adamdır. Eichmann’ın savunması boyunca resmi bir dille "nihai çözümden” söz etmesi (zira Nazi rejimi, Yahudileri sürmek, toplamak ya da "nihai çözüme" başvurmak -yani öldürmek- şeklinde üç yönteme başvurmuştur) ve sadece emirleri yerine getiren sıradan bir memur olduğu konusunda israr etmesi, Arendt'e göre, "kötülüğün sıradanlığına" delalet etmektedir. Üstelik soykırıma giden yolların taşlarının 
“The Banality of Evil”: Reading Alexander Solzhenitsyn's Impressions of Soviet labor camps through Hannah Arendt's concepts / D. Özakın (p. 431-449)

döşendiği ihbar, yakalanma ve tehcir süreçlerinde, bizzat Yahudi yetkililerle işbirliği yapılmıştır; bu da kötülüğü daha yaygın ve çok merkezli kılmıştır (Arendt, 2009, s.126). Arendt'e göre, simgesel bir biçimde, başlıca yetkili olarak Eichmann’ı suçlu göstermek anlamlı görünmemektedir.

Arendt, "kötülüğün sıradanlığı" kavramıyla, 1960'lı yıllarda tartışmalara neden olan savını ortaya koymuştur. Arendt’in çıkarımlarına göre Eichmann, sadece iyi bir devlet memuru olmaya çalışan sıradan bir adamdır. Totaliter Nazi rejiminin insanlık dışı uygulamaları esnasında kötülük, olağan hale getirilmiştir. Zira üst düzey Yahudilerin de "kötülük" sürecine dahil olması, Arendt'e göre bir çeşit "ahlaki çöküntü" yaratmıştır. İtaatin değerli kılındığı bir perspektiften bakıldığında, topyekûn bir akıl tutulması sürecinde Eichmann, sadece emirlere itaat eden çalışkan bir memurdan başka bir şey değildir. Asıl mesele, kötülüğün rasyonalize edilmesi, sıradanlaşması ve trajik sonuçlarının dahi bir görev zinciri içinde olağanlaşması olmuştur.

Dava boyunca Eichmann, savunmasında, yasalara ne kadar bağlı bir vatandaş olduğunu, söz konusu katliamların halkalarından birinde yer almıyormuş gibi, soğukkanlı bir tavırla ifade etmektedir. Tüm yaptığı, "yasalar çerçevesinde" emirleri yerine getirmekten ibarettir (Arendt, 2009, s.143). Arendt'e göre, Eichmann ve onun gibi davasına bağlı yetkililerin en büyük suçu, "fikirsizlik"tir; yani eylemlerinin varacağı sonuçları düşünme yetisinin rafa kaldırılmış olmasıdır. İnsanlık suçu işleyenler, esasında birer "canavar" değildirler, sıradan insanlarla aynı özellikleri taşıyan yetkililerdir ve üstlerine karşı itaatkâr kimselerdir.

\begin{abstract}
"Savaş sonrası davalarda, diğer sanıklar gibi Eichmann da kendisini, suçları kendi iradesiyle işlemediği, yalnzzca yasaların gereğini yerine getirdiği, kendisi yapmasa başkalarının yapacağın söyleyerek savunmaktadır. Kısaca şunu demektedir: 'Bu suçları ben değil, içinde yer aldığım düzen ve koşullar gerçekleștirmiștir.' Sankklar, suça ortak olurken eylemlerinin üzerinde düşünüp karar vermemişlerdir. 'Hükümranlık anlayış'na göre yüce makamlarn verdiği emirler yasal ve hukuka uygundur. Bu emirler yargilanamaz emirlerdir. Eichmann da eylemlerinde hükümranlık anlayışına uygun olarak eylemlerde bulunmuştur" (Erdem, 2010, s.10).
\end{abstract}

Erdem, Hannah Arendt'in Eichmann Davası’na ilişkin görüşlerini tartışırken, adalet ve özgürlük düşüncesini, siyasetle beraber ele almak gerektiğini ortaya koyar. Nazi suçlularının mahkemelerde verdikleri ifadeler, dönüp dolaşıp aynı savunma üzerinde birleşmektedir: "Biz yapmasak başkası yapacaktı. İddia edilen suçları kabul etmiyoruz. Biz hiçbir insanın öldürülme emrini vermedik. Emirleri ve yasalar uygulamaktan başka yapılacak bir şey yoktu.” Erdem'e göre, Arendt düşüncesinde, yönetime itaat edenler, totaliter düzenin emirlerini yerine getirirken, "insan onuruna aykırı bir düzenin devamını da sağlamışlardır"; "kötülük ve fikirsizlik bu durumda birbirleriyle iç içe geçmiş bir ilişkiyi dile getirmektedir" (Erdem, 2010, s.13-14).

Kamp sistemi bağlamında, totaliter rejimlerin eylem mekanizmalarında yer alan yetkililerin vicdanî çıkmazı bu noktada şekillenmektedir. Kişinin vicdanî kabullerine aykırı dahi olsa, insan eliyle yazılmış güncel yasalar çerçevesinde hareket eden bir dizi "fikirsiz"in itaatkârlı̆̆ı, kötülüğü beslemekte ve anonimleştirmektedir. Bu "fikirsiz" eylemler, kötülüğün kaynağına, muğlak bir nitelik kazandırmaktadır.

Arendt, "Totalitarizmin Kaynakları"nın ilk elyazmasını, 1949 güzünde, "Hitler Almanyası'nın yenilgisinden dört sene sonra, Stalin’in ölümüne dört seneden az bir süre kala" tamamlandığını not eder. Kitabın ilk baskısı 1951'de yapılmıştır. Kitabı yazmaya başladığı 1945’ten sonraki yılların, “on yıllarca süren kargaşa, çalkantı ve düpedüz dehşet döneminin, türlü türlü yeni tiranlıkları" takip ederek kitle desteğine kavuştuğunu belirtir. Birinci Dünya Savaşı’nın ardından gelen devrimler, totaliter 
hareketlerin yükselişi ve parlamenter yönetimlerin gerilemesi, faşist, yarı-faşist iktidarlardan tek parti diktatörlüklerine ve askerî diktatörlüklere geçiş (Arendt, 2014, s.9), bu dehşet dönemini karakterize eden olumsuz gelişmeler arasında sayılmaktadır.

Arendt'e göre savaşın bitmesi, Rusya'da totaliter yönetimin çökmesi anlamına gelmemiştir. Tam aksine savaşın bitimiyle, Doğu Avrupa'nın "Bolşevikleştirilmesi” başlamış, böylelikle totaliter yönetim yayılmaya devam etmiştir. Barış süreci, iki totaliter rejimin (Nazi Almanyası ve Sovyet Rusya) "yöntemleri ve kurumları arasındaki benzerlik ve farklhlkları analiz etmek için kerteriz alnabilecek bir dönüm noktası olmaktan öte bir anlam taşıma[mıştır]" (Arendt, 2014, s.12). Bu bağlamda çalışma, Nazi ve Sovyet dönemlerinde ortaya çıkan kamp düzeninde, insanı bedensel gereksinimlerini öncelemeye iten uygulamaları, 20. yüzyılın etkin düşünürlerinden Hannah Arendt’in "kötülüğün sıradanlığı" teziyle; totalitarizme ve toplama kamplarına ilişkin değerlendirmeleri yoluyla açılkamayı hedefler. Böylelikle, bir mahkûmun tek bir gününü, bütün teferruatıyla ortaya koymaya çalışan Soljenitsın'ın sıklıkla yer verdiği bedensel tecrübenin, kamp sistemiyle nasıl şekillendiği ve medeniyetyabanıllık olarak etiketlediğimiz dikotominin kampın sınırlarında nasıl kolaylıkla ters yüz edildiği ortaya konacaktır.

\title{
Otobiyografik bir eser olarak "İvan Denisoviç’in Bir Günü"
}

İngiliz tarihçi Geoffrey Hosking’e göre, Sovyet yazar ve şair Aleksandr Tvardovski’nin edebiyat tarihine en büyük katkısı, 1962 yılında Aleksandr Soljenitsın’ın "İvan Denisoviç’in Bir Günü” başlıklı romanını yayınlamasıdır. Eser, ilk olarak, Tvardovski'nin editörlüğünü yaptığı "Novıy mir" dergisinde tefrika edilmiştir. Bu romanında Soljenitsın, Gulag'daki sefaleti, zalimliği ve kampın insanlık dışılığını gözler önüne serer (Hosking, 2011, s.765).

“Kamp Gerçeğinden Edebiyata: İlk Çember, İvan Denisoviç’in Bir Günü, Gulag Takımadaları” adlı çalışmasında Kaşoğlu, Stalin döneminde rejim karşıtı olmakla suçlanan çok sayıda insanın, sürgün adı altında ıslah-çalışma kamplarına gönderildiğini, bu olumsuz tecrübelerini eserlerine aktaran en dikkat çekici yazarlardan birinin Soljenitsın olduğunu ifade eder. Kuşkusuz bunda, yazarın kendisinin de bu kamplara gönderilmiş olmasının etkisi vardır. Kaşoğlu, 1950-53 yıllarında Ekibastuz Kampı'na gönderilen yazarın, burada geçirdiği günlerinden izlenimleri, “İvan Denisoviç’in Bir Günü” adlı eserinde ortaya koyduğunu belirtir (Kaşoğlu, 2014, s.400).

\begin{abstract}
"1950 yılında yazar yalnzzca siyasî mahkûmlarm bulunduğu özel bir kampa gönderilir. Burası Orta Asya Kazakistan Sovyet Cumhuriyeti”nde, Pavlodar Eyaleti'nde bulunan Ekibastuz'dur. Ekibastuz, Gulag'a bağlıdır. Ekibastuz, kömür yataklarıyla zengindir; Sovyet Cumhuriyetïnde maden ocaklar bulunan yerlerde mahkûmları çalş̧tırmak bir gelenektir. Burada bulunduğu dönem içinde yazar, eşi Resetovskaya'dan ayrllır. Bunun nedeni yazarın sürgün ve hapis yillarmın ne kadar süreceğini bilmemesidir. Soljenitsın bu kampta geçirdiği zor zamanlar kâğıda dökmek ve bu insanllk dışı vahşeti paylaşmak ister. Böylece çalışma kamplarını boş, basit, monoton ve korku dolu sistemini açıcça gözler önüne seren 'İvan Denisoviç̧in Bir Günü' eserinin temelleri burada atılır. Daha sonra yazar, buradaki zor iklim şartlarını ve acımasız yaşamı bir mahkûmun yalnızca bir günü ile ustaca dile getirecektir" (Can, 2010, s.12-13).
\end{abstract}

“Tarih-Edebiyat Bağlamında A. Soljenitsın’ın Eserlerinde Figürler” adlı çalışmalarında Çelik ve Can, Soljenitsın'ı “iki dünya savaşını yaşamış ve 1917 Ekim Devrimi ile yeni bir yönetim sistemine geçmiş, dolayısıyla, toplumsal yapının topyekûn değişmiş olduğu bir dönemin yazarı" olarak nitelerler (Çelik \& Can, 2010, s.272). Yazarın kamp gerçeğini bütün ayrıntılarıyla okura aktarabilmesinde; en sıradan görünen ve gündelik yaşamın içinde kendiliğinden akıp giden bazı düşüncelerin ve eylemlerin arka planında gizlenen tarihsel alt metnin zenginliğinde, söz konusu otobiyografik kurgunun etkileri 
“The Banality of Evil”: Reading Alexander Solzhenitsyn's Impressions of Soviet labor camps through Hannah Arendt's concepts / D. Özakın (p. 431-449)

gözlemlenebilir. Soljenitsın "kendisinin de yaşadığı bir trajediyi, Sovyet döneminin bir olgusu haline gelen kampları ve bu kamplarda ayakta durmaya çalışan insanların dünyasını eserlerinde, kuşkusuz, deneyimleri doğrultusunda kendi düşünsel ideolojik süzgecinden geçirerek tüm gerçekliği ile" yansıtmıştır (Çelik \& Can, 2010, s.272).

Bu bilgiler ışığında, yazarın 1962 tarihli romanını analiz etmek için en uygun yöntem, metnin otobiyografik ve tarihsel-gerçekçi unsurlarına odaklanmak olacaktır. Çalışma, kamp gerçeğini karakterize eden tarihsel kesiti ve olguları, Soljenitsın'ın bizzat tecrübe ederek kurguya aktardığı yönleriyle, Arendt'in "Kötülüğün Siradanlığı: Adolf Eichmann Kudüs'te" adlı eserinde ortaya koyduğu "kötülüğün sıradanlığı" kavramsallaştırmasından ve "Totalitarizmin Kaynakları" ve "Şiddet Üzerine" adlı eserlerinde dile getirdiği, -başta Nazi Almanyası ve Stalin Rusyası'na yöneltilenler olmak üzeretotaliter rejimlere ilişkin eleştirilerinden yola çıkarak ele alacaktır.

\section{Analiz ve bulgular}

İvan Denisoviç Şuhov'un içinde bulunduğu kamp düzenindeki zalimliği, insanlık dışı uygulamaları; yani "kötülüğü" tesis eden belli başlı unsurlar siyasal olan en geniş çemberden başlamakta; biyolojik olan dar çembere dek daralmaktadır. Çemberin merkez noktasında, insanın hayatta kalmak için karşılamaya mecbur olduğu birincil-bedensel ihtiyaçları yer alır. Tüm bu düzeneği kuşatan asıl dayanak noktası ise, kampın gerekçelendirilmesine yarayan hukuk sisteminin, totaliter rejim lehine yeniden düzenlenmiş olmasıdır.

Analiz ve bulgular bölümünde, bu çemberler dıştan içe doğru değerlendirmeye alınacaktır. Öncelikle Gulag mahkumiyetini de kapsayan cezaların normalleştirilmesi ve gerekçelendirilmesi için kapsamı genişletilen "vatana ihanet" suçunu ifade eden 58. maddenin kapsamı açlklanacak, bu maddeyle totaliter rejimin yurttaşlık tanımının nasıl aynı anda hem kapsayıcı hem de dışlayıcı olabildiği tartışılacaktır. Daha sonra kampın sınırlarını belirleyen fiziksel unsurlar olarak soğuk hava, dikenli teller gibi kampa ilişkin simgeler ele alınacaktır. Nihayet merkez noktasındaki biyolojik çembere dâhil olan temel ihtiyaçları temsil eden "ekmek" simgesi ve mahkumların karnını doyurabilmesine ilişkin mücadele süreçleri değerlendirilecektir.

\section{8. madde: Cezaların normalleştirilmesi ve gerekçelendirilmesi}

Sovyet tarihinde 58. madde, sistem karşıtı olduklarından şüphe edilen vatandaşların suçlanmasına dayanak olarak gösterilen ve içeriği muğlak olan "vatana ihanet" suçunu ifade etmektedir. 58. madde, 1922 yılında yürürlüğe giren, 1926 yılında kapsamlı bir düzenlemeden geçen ceza kanununun maddeleri arasında yer alır. Devlet aleyhine "kanıtlanmamış" faaliyetlerde bulunmak da, casusluk "şüphesi" taşımak da, 58. madde kapsamındaki suç tanımına uygun bulunmuştur. Ceza kanununda yer alan 58 . madde sayesinde, terör suçunun kapsamı genişletilmiştir ve ilgili kanun Stalin’in ölümüyle yönetimin el değiştirmesine dek yürürlükte kalmıştır. Stalin sonrası dönem reformları çerçevesinde, askeri ve olağanüstü hal mahkemeleri kaldırılmış, yetkileri kısıtlanmıştır. Ceza yasası ise, haksız tutuklamalara ve "göstermelik" mahkemelere dayanak oluşturduğu gerekçesiyle "karşı devrim hareketi", "terörist amaçlar” gibi bazı belirsiz ve yoruma açı ifadelerden arındırılmıştır (Hosking, 2011, s.735).

Hannah Arendt, ceza yasasının geçerli olduğu süreci, bilim insanlarından devlet kadrolarına dek pek çok kişinin tasfiye edildiği, vatana ihanet gibi genel geçer ve somut olmayan suçlarla kamplara ve akıl hastanelerine kapatıldı̆̆ dönem olarak tanımlar. Vatana ihanet suçunun bir dayanak olarak 
yaygınlaşmaya başladığı döneme de vurgu yapan Arendt, "Büyük Temizlik" (Bol'şaya çistka) yılları boyunca (1936-38), önce suçun icat edildiğini; daha sonra bu suça uygun suçlular türetildiğini vurgulamak üzere; Stalin’in, tasfiye etmek istediği veya tasfiye hazırlıkları yaptığı herkesten şüphelendiğini, hatta partinin ve yönetimin üst kademelerindeki hemen herkese şüpheyle yaklaşmış olduğunu (Arendt, 2014, s.18) belirtir.

Romanda da "düşmana esir düşenlerin hepsi casus sayıldiğı için" (Kaşoğlu, 2014, s.404) Şuhov kendini kampta bulmuştur. Eserde Şuhov için "hakkında 'yurda ihanet' suçundan dolayı soruşturma açılmış, bu suçlamayı destekleyecek biçimde ifade vermişti” (Soljenitsın, 2004, s.62) sözlerine yer verilir. Zira "ceza yasasımm 58. maddesine göre hüküm giyenler, genel kamplardan özel kamplara gönderilmiştir" (Soljenitsın, 2004, s.41). Şuhov, 58. madde [maddenin 14. paragrafında yer alan "devrim-karşıtı sabotaj, yani, birinin belirli görevleri yerine getirme konusundaki bilinçli başarısızhğı ya da hükümetin gücünü ve devlet aygıtınn faaliyetlerini zayıflatmak amacıyla özel olarak onlar ihmâl etmesi” (RSFSC Ceza Kanunu3, 1950, s.43)] uyarınca kampa gönderilmiştir.

Eserde gardiyan ve yöneticilerle tartışan mahkûmlar on günlük hücre hapsine gönderilir. Bu süre zarfinda ekmekten başka bir şey verilmeyen mahkûmlar genelde on günü tamamlayamadan ölürler, sağ kalanlar ise ömür boyu sürecek ciddi hastalıklara maruz kalırlar. Özel kamplarda diledikleri gibi yüksek sesle fikirlerini dile getirebilirler; diğerlerinde ise, "dışarıda kibrit sıkıntısı çekildiğini söyleseniz sizi hücreye tıkarlar" (Soljenitsın, 2004, s.142). Devletin sadece siyasi değil, ekonomik yönden de zorluklarla mücadele ettiğini ima eden en masum yorumun karşıllğı, hücre hapsiyle cezalandırılmaktır.

Mahkûmlar, hücreye düşmedikçe, kendilerini mutlu sayarlar (Soljenitsın, 2004, S.151). Eserin kahramanı Şuhov, kendisiyle ve düşünceleriyle baş başa kalmaktansa yorucu bir çalışma gününü yeğler. Zira "İvan Denisoviç̧in iç çatışma yaşadığı anlar; bir insanın iç dünyasındaki yapı taşlarımı, kişiliğini oluşturan kendi değerleri ile yaşamış olduğu dış dünyanın acımasız, yalın gerçekliği karşısındaki değer yargılarının çatışması ve kendisiyle hesaplaştı̆̆ anlardır" (Şahinkaya, 2013, s.86). Şuhov bu düşüncelerini "iş cezası gene o kadar ağır değildi. Sıcak yemek verilir ve insan kendini kara düşüncelere kaptırmazdı. Ama hücre cezası bütün bütüne kötüydü” (Soljenitsın, 2004, s.9) sözleriyle dile getirir.

Mahkûmların ceza süreleri de, hüküm giyme nedenleri kadar muğlaktır. Kamptaki hiçbir sürgün, cezasının biteceği günü umutla bekleme hakkına dahi sahip değildir: "Asıl cezası üç yıl olanlar, fazladan bir beş yıl yatmamışlar mıydı? İstedikleri yasayı çıkarıyorlardı. On yıl bitince 'Hadi bir on yıl daha yat!" derler, en azından insanı memleketinden başka bir yere gönderirlerdi” (Soljenitsın, 2004, s.62) Zira Stalin diktatörlüğü döneminde "herhangi bir suçu olmayan suçlulardan ve ihbar selinden" söz edilmektedir (Arendt, 2014, s.23). Yönetim, bu ihbar selini gerekçelendirebilmek adına, Gulag mahkumlarının en temel yurttaşlık haklarını ihlâl eden bir dizi düzenleme yapmak durumunda kalmıştır.

\section{Totaliter rejimin yurttaşlık tanımı}

Hannah Arendt, Nazizm ve Stalinizmin özünün, sadece geleneksel politika, hukuk, etik ve felsefe kategorilerine dayanarak açılanamayacağına inanır; zira totaliter rejimlerin doğası, yalnızca devlet yöneticilerinin iktidar, kanunsuzluk, ahlaksızlık ya da nihilizm arzusunun basit bir tezahürü olarak yorumlanamaz (Malışev, 2010, s.300-301). Totaliter rejim yasal ile yasadışı olan; meşru ve gayrimeşru

3 Rusya Sovyet Federatif Sosyalist Cumhuriyeti Ceza Kanunu (Ugolovnıy Kodeks RSFSR). 
“The Banality of Evil”: Reading Alexander Solzhenitsyn's Impressions of Soviet labor camps through Hannah Arendt's concepts / D. Özakın (p. 431-449)

olan arasındaki geçişkenlikten istifade eder. Bu sistemde, hala yasanın üstünlüğü kabul ediliyormuş gibi görünmektedir; oysa yasa, gayrimeşru faaliyetleri aklamak adına esnetilmekte, kapsamı giderek genişletilmekte ve içeriği belirsiz hale getirilmektedir. Eserde bu durumun 58. maddeye atıf yapılan sahnelerde somutlaştığı görülmektedir. Bu süreçte yurttaş, hala yasaya tabi sayılsa da, yasal ve yasa dışı olan arasındaki uçurumdan aşağı itilmektedir.

“Modern Yurttaşlığın İstisnaları: Hannah Arendt ve Giorgio Agamben’in Görüşleri Çerçevesinde İnsan Haklarının Eleştirisinde Mülteciler ve Kamplar" adlı çalışmasında Yılmaz (2018, s.765) "insanlar yurttaşlıktan çıkarılıp çıplak haliyle ortada kaldıklarında, yani 'insan' olmaları sahip oldukları tek kimlik olarak kaldığında, bu hakların da ortadan uçup gittiğini” belirtir. Bu durumda, yurttaşlarla eşit haklara sahip sayılmayan 'çılak insan'lar "ilk olarak yurtlarını, ardından siyasi bir yönetimin korumasını kaybetmişlerdir” (Yılmaz, 2018, s.766). Okur, romanda Gulag mahkûmlarına birer yurttaş olarak haklarını vermeyen sisteme yönelik eleştirilerle karşılaşır. Soğukta mahkûmları soyarak aramaları üstüne eski bir yüzbaşı olan mahkûm Buynovski, yetkililere şöyle bağırır: "Bu soğukta insanlar soymaya hakkımı var mı? Ceza yasasınm dokuzuncu maddesini biliyor musunuz? (...) Siz Sovyetler Birliği yurttaşı değil misiniz? Nasıl komünistliktir bu!" (Soljenitsın, 2004, s.32).

Yurttaşlık haklarının kaybı, Şuhov'un geleceğe ilişkin hayal kurmayı bırakmasına neden olmuştur. Zira "kamu görevi hakları elinden alındiğı için ona hiçbir yerde iş vermezler" (Soljenitsın, 2004, s.40). Şuhov, Yılmaz’ın ifade ettiği gibi "siyasi bir yönetimin korumasını" kaybetmiştir. "Peki, siyasi bir yönetimin korumasın kaybetmek ne demekti? Hakları kurumlar yaratır ve haklar yaratan kurumlar ile onları ortadan kaldıran, tahrip eden kurumlar aymıdı" (Yılmaz, 2018, s.768). Haklarının vatandaşı olduğu devlet tarafindan tahrip edilmesiyle Gulag mahkûmu, artık bir yurttaş değil, sadece bir bedendir, doğaya ait bir 'corpus'tur. İşte bu 'corpus'un (özne olarak değil; cisim olarak beden) yaşamasını sağlamak için insan, sosyal yeteneklerinden sıyrılarak biyolojik yönüyle baş başa kalır. Burada doğrudan bedeni etkileyen barınma, ısınma, beslenme gibi hayatta kalmaya yönelik unsurlar karşımıza çıkar.

Agamben'in (2017: 12) sözünü ettiği "bir dizi amaca uygun teknoloji kullanmak suretiyle deyim yerindeyse kendisine gereken 'uysal bedenler’ y aratan yeni biyo-iktidarın ulaştı̆̆ disiplinci denetim”, romanda, cezalıların sadece bedensel işgücünü ifade etmeleri bakımından değerli sayıldıkları bölümlerde karşılığını bulur. Mahkumlar çalışma saatlerinde değil, geceleri, dinlenme saatlerinde cezalarını çekerler: "Cezalıy gündüzleyin hücreye kapatmazlardı, bir adamın işten eksik olması demekti bu. Gün boyunca canını çıkarırlar, akşamleyin de hapse atarlardı" (Soljenitsın, 2004, s.33).

Nöbetçiler ve teğmenler için kamp düzeninde insan elbette bir değer taşımaktadır; ancak bu değeri hümanist bir yaklaşımla değil, can havliyle verirler: "İnsan altından da değerliydi. Parmaklıklarm ötesine bir kelle eksik çıkarsa bunu kendi kellenle tamamlardın" (Soljenitsın, 2004, s.34). Kamp düzeninde kötülüğü olağan kılan ve ona karşı çıkmayı engelleyen bir çark vardır. Özgür seçimler yapmak yerine yasalara koşulsuz itaat etmek, yaşamı kurtarmaktadır. Yurttaşlık haklarını yitirdiği ve diğer mahkûmlarla dayanışmasının engellendiği çetin koşullarda insan, bencil bir varlığa dönüşmek zorunda birakılır.

\section{“Sibirya Soğukları", dikenli teller ve anlamlandırılan uzam}

Rus topraklarının en soğuk bölgelerinden biri olan "Sibirya'ya sürülmek” ve “Sibirya soğukları" gündelik dilde dahi yansımasını bulmuş bir tarihsel gerçeklik olarak karşımıza çıkar. Bu tarihsel gerçeklik aynı 
zamanda, edebî yapitlarda "geleneksel tema veya öge" biçimine dönüşmüş ve pek çok yazar tarafından yinelenen bir simge halini almıştır.

"Sibirya, birbiriyle iç içe olan iki anlam içerir: biri, topografya alanı, içerisinde derya gibi zenginlikler barındiran bir coğrafya, diğeri ise siyasal, toplumsal, kültürel bir alan, binlerce sürgünün ve hükümlünün kaderini, hayallerini içinde taşıyan, birçok yazarm eserlerinde yer verdiği “imajlar, motifler halinde’ bir topos” (İnanır, 2018, s.65).

Eserde mahkûmların, onları güçsüz bırakan, kamptan kaçabilme şanslarını engelleyen, hapsedilmişlik duygusunu ikiye katlayan ve hareketlerini kısıtlayan bir etken olarak soğuk hava ile ilişkilerine sıklıkla değinilir: "Soğuk bir kere gömleğin altına girdi mi, bir daha çıkmak bilmezdi. Üst üste ne kadar giyinirsen giyin, hepsi boş” (Soljenitsın, 2004, s.33). Şüphesiz soğuk, Rus tarihinde sürgünleri ve sürgün edilmenin biçimlerinden biri olarak kamp cezasını kuşatan temel simgelerden biri haline gelmiştir. Soğuk hava mahkûmları gerek fiziksel gerek psikolojik bakımdan ezmektedir. Hava eksi otuz dereceyi gösterdiğinde bile "üşümeleri soğuktan çok, bütün günü bu ayazda geçirme korkusundandrr" (Soljenitsın, 2004, s.11). Hava ancak eksi kırk bir dereceyi gösterirse, çalışmaktan kurtulabilirler. Tek ısınma yolu çalışmaktır (Soljenitsın, 2004, s.51). Dayanılması güç soğuklarla şekillenen kamp uzamında tabloyu tamamlayan simgelerden bir diğeri de, gerek Nazi, gerekse Stalin kamplarıyla özdeşleşen dikenli tellerdir.

\begin{abstract}
"Büyük Terör süreciyle beraber, kamplarm niteliklerinde ve çalısma sistemlerinde de köklü değiş̧iklikler meydana gelmiştir. Çalş̧ma kampları ve sürgünler, Stalin dönemi Sovyet günlük yaşamının bir parçası haline getirilmiştir. Her an bu zincirin bir halkası olabileceğini düşünen insanlar dikenli tellerin ardında büyük bir korku ile yaşarken, dikenli tellerin içinde ayrı bir dünya hüküm sürmektedir" (Gürsoy, 2018, s.413).
\end{abstract}

Romanda, Şuhov'un mahkûmiyet yıllarında bir "Sosyalist Yaşam Sitesi” kurulması planlanmaktadır. Şuhov, çetin doğa koşulları nedeniyle boşluktan başka şey ifade etmeyen düzlükleri, sistemin simgeleriyle donatmak adına çektikleri sıkıntının tüm adımlarını aktarır: "SYS denilen yer şimdilik kar yığınları altında bir tarlaydı. Önce burada çukurlar açıp direk dikmek, sonra kendi çevrelerine dikenli tel çekmek gerekiyordu. En sonra da site kurulacaktı" (Soljenitsın, 2004, s.7).Doğa ile mücadeleye girişen Sovyet hükümeti doğada yeni bir düzen yaratma (nehirleri ve gölleri, çağlayanları ve kayaları rasyonel olarak düzenleme) planını gerçekleştirmiştir (Sokolova, 2013, s.9). Gulag kamplarının ülkenin en ücra köşelerinde konuşlandırılması da bu amaca hizmet etmiştir.

"Rusya Tarihinde ve Edebiyatında Sibirya'ya Genel Bakış" adlı çalışmasında Çelik (2018, s. 16) Sibirya topraklarının 16. yüzyıldan itibaren Rusların kolonizasyon sürecinin hedefine yerleştirildiğini belirtir ve bu sürecin Avrupalı devletlerce yürütülen sömürgecilikten farkını şöyle dile getirir: "Rus sömürgeciliği Batı Avrupa sömürgeciliği gibi deniz aşırı değil, sert iklimi olan bölgeye kara yolu üzerinden yapılan bir sömürgeciliktir. (...) Ayrıca istilâ edilen topraklar da ilk defa keşfedilmiş yerler değil, önceden de bilinen ama sahip olunamayan topraklardır" (Çelik, 2018, s.16). Bu topraklara sahip olabilmek için kimi zaman zorunlu iskân politikaları uygulanmış, kimi zaman da sürgün cezasına çarptırılan mahkûmların işgücünden istifade edilmiştir.

"Dikenli Teller: Modernleşmenin Ekolojisi” (Barbed Wire: An Ecology of Modernity) adlı çalışmasında Reviel Netz, (2004, s.182) Sovyet toplumunun özünü, mekân üzerinde kurulan devlet kontrolü olarak tanımlar. Kamp uzamını ablukaya almak için ihtiyaç duyulan dikenli teller, Gulag'ın ilk dönemlerinde oldukça maliyetli bir çözüm yolu olarak kabul edilse de, 1948 yılının ortalarında, kamplarda kullanılmak üzere sekiz yüz ton dikenli tel talep edilmiştir. Böylelikle dikenli teller, kolonizasyonun bir aracı haline dönüşmüştür. Yeni topraklar, dikenli tellerle çevrilen kamplar sayesinde, insan yerleşimine açllmıştır. 
“The Banality of Evil”: Reading Alexander Solzhenitsyn's Impressions of Soviet labor camps through Hannah Arendt's concepts / D. Özakın (p. 431-449)

Gulag'n coğrafi öneminin vurgulanması gerektiğini ifade eden Netz, kampta zorunlu çalışmanın Sovyet sisteminin temel projesine, yani, Sovyet topraklarını kontrol altına almaya hizmet ettiğini belirtir (Netz, 2004, s.188).

Romanda Gulag mahkûmlarının iş gücü, bomboş, uçsuz bucaksız görünen bir arazinin anlamlandırılması üzerine kuruludur. "Yaratıldığından beri bu bozkırda hiçbir şey yetişmemişti, hele dikenli teller arasında bir otçuk bile...” (Soljenitsın, 2004, s.67). Bu anlamlandırma sürecinin en önemli göstergelerinden biri, kamp yaşamını ve hapsedilmeyi simgeleyen dikenli teller olacaktır: "Kamp firınını hükümlülerin saldırısından koruyan dikenli telleri geçtiler” (Soljenitsın, 2004, s.11). Yetkililer, soğuk havalarda açık arazide çalışırken hükümlülerin donmasından değil, kamptan kaçıp gitmelerinden korkarlar. Ancak Şuhov'un “dikenli telleri aşsalar bile, nereye gideceklerdi ki?” (Soljenitsın, 2004, s.48) sözleri, mahkûmların özgürlük umudunun dikenli teller tarafından kuşatılmış olduğunu ifade etmesi bakımından önemlidir. Doğa koşulları öylesine çetindir ki, dikenli tellerin ardı, bir müddet sonra hükümlülere "güvensiz bölge" gibi görünmeye başlamıştır ve onların düşüncelerini de sınırlarını dikenli tellerin belirlediği kamp alanına hapsetmiştir. ${ }^{4}$

Şuhov'un tasvirleri, kamp anlatılarında okurun karşısına çokça çıkan ve kamp hikayeleriyle özdeşlemiş iki simgeyi vurgular: Kar örtüsü ve dikenli tellerden oluşan bir çerçeve. "Bembeyaz kar örtüsü üzerinde görülen gözetleme kuleleri ve dikenli tel direkleri çepe çevre dolanıyordu” (Soljenitsın, 2004, s.85-6). Cezalıların kaçmasını önlemek için her türlü ihtimal göz ününde bulundurulmuştur. Bu nedenle "kamplarda bütün kapılar içeri açılırdı. Arkadan bütün hükümlüler yüklenseler bile dışarı doğru açamazlardı"(Soljenitsın, 2004, s.122). Netz, Gulag’ın mahkumlar tarafından inşa edildiğini; öte yandan hükümlülerin geniş çaplı ulaştırma projeleri için çalıştırıldıklarını belirtir ve bu durumu "Sovyet toprakları üzerine kurulmuş bir başka modernleşme rüyası” olarak yorumlar (Netz, 2004, s.188). Mahkûmları akıl almaz bir çelişki içinde bırakan uygulama, hükümlülerin aşabileceği (ve kaçabileceği) düşünülen çitlerin, yine mahkûmlar tarafından onarılmasının zorunlu tutulmasıdır. Bu işler, mahkûmların izinli olduğu pazar günleri angarya olarak bizzat kendilerine yaptırılır (Soljenitsın, 2004, s.126). Mahkûmlar, kendi "özgürleşme ihtimallerine" karşı, kampın çevresine çit çekmek için çalışmak zorunda birakılırlar.

\section{Ekmek}

Gulag mahkumları için ekmek simgesinin önemini açıklayabilmek adına, öncelikle eserde gündelik hayatın ritminin ve onun yinelenerek anlam kazanan bütün safhalarının tespit edilmesi gerekir. oman, "her sabah olduğu gibi saat beşte" (Soljenitsın, 2004, s.5) kalk işaretinin verilmesi ile başlar. "Ayaz, karanlık, karınlar aç, koskoca bir günün başlangıcı” (Soljenitsın, 2004, s.26). Kalk işaretinden işbaşı yapılana kadar geçen zaman "devletin olmadığı için herkes istediği gibi kullanır" bu nedenle Şuhov, bunu değerlendirmek için hemen kalkar (Soljenitsın, 2004, s.5). Ceylan, Soljenitsın'ın eseri yazma kararı aldığı ve kurgunun çerçevesini bir günü kapsayacak biçimde şekillendirdiği süreci şöyle aktarmaktadır:

"1950 yılında, kamp yaşamını uzun kış günlerinden birinde mesai arkadaşımla teskere taşıyordum ve 'Bütün bu kamp yaşamın nasll tasvir edebilirim?' diye düşündüm. Aslında en

\footnotetext{
$4 \quad$ Soljenitsın’ın kamp mahkumlarının zorlu yaşam mücadelesini ve siyasi suçlulara yönelik zulmü konu edindiği geniş kapsamlı yapıtı “Gulag Takımadaları”nın (Arhipelag GULAG) dördüncü bölümü “Ruh ve Dikenli Teller” (Duşa i kolyuçaya provoloka) başlı̆̆ını taşır (Soljenitsın, 2006, s.484). Yazar, doğal olarak kimsenin hükümlülerin ruhlarıyla ilgilenmediği çalıştırma kampında, ruhun teslim olmamasının, direnmesinin, manevi yükselişin mümkün olup olmadığını sorgular (Soljenitsın, 2006, s.492). Bu sorgulamayı, sınırları dikenli tellerle belirlenmiş kamp bölgesi (zona) ve ruhun tutsak edilişi arasında doğrusal bir bağ kurarak ifade eder.
} 
suradan işçilerden birinin bir gününü ayrntılı bir şekilde, ama en küçük ayrntıyı bile vererek anlatmak yeterli gelecektir, çünkü burası bizim bütün yaşamımızı gözler önüne sermektedir. Hatta birtakım felaketlere yer vermek bile gereksiz, öyle özel bir günün olması da gerekmiyor, bu yılları gözler önüne seren bir gün, stradan bir gün olmalıyd. Bu şekilde düşünmeye başladım ve aklıma bir fikir geldi. Dokuz yıl bu düşünceye elimi sürmedim ve ancak 1959 yılında, yani dokuz yıl sonra başına oturdum ve yazdım” (Klimov'dan akt. Ceylan, 2015, s.72).

Soljenitsın’ın eserinde, mahkûmların yaşamındaki her şüpheli hareketin, kamp kurallarından sapma olarak nitelendirilip, onların cezalarını uzatabileceği üzerinde durulur. Mahkûmlar, nasıl nedensiz yere, 58. madde gibi içeriği esnetilen bir ithamla içeri atıldılarsa, aynı dayanaksız fakat zorba yöntemlerle cezalarının uzatılabileceği endişesi pek çok pasajda tekrarlanır.

Romanda, kampın sıkı kurallarını belirleyen etkenlerden biri, mahkûmların temel yaşamsal ihtiyaçlarını normale yakın olarak karşılamaları durumunda, fiziksel güç bulup kamptan kaçabilecekleri ihtimalidir. Bunun için yeterince tok olmaları, daha sonra yemek üzere yiyecek saklamaları, yeterince ısınmaları ve onların birer kamp mahkûmu olduklarını açıkça belli edecek üniformaları dışında sivil giysilere sahip olmaları engellenir: "Sabahleyin araştırılan bir başka şey de hükümlü giysisinin altına sivil giysi giyilip giyilmediğiydi. Oysa bütün sivil giyecekler daha kampa geldikleri sırada ellerinden alnmışt, buradan ayrlacakları zaman da geri verilecekti. Fakat hiç kimse ceza sürelerinin ne zaman biteceğini bilmiyordu" (Soljenitsın, 2004, s.31).

Kısıtlı miktarlarda dağıtılan ve mahkûmların firsat bulabilirlerse giysilerinin ceplerinde veya yataklarında sakladıkları ekmek, eserin önemli leitmotivlerinden biridir. Temel yaşamsal ihtiyaçların başlıcasını karşılayan ekmek, kamp mahkûmlarının yaşayabilmek için, ancak daha çok çalışarak ulaşabilecekleri gündelik bir ödüle dönüşmektedir. "Çünkü adam bununla kaçabilirdi. Hatta bir zamanlar öğle yemeklerinde verilen iki yüz gram ekmekten bile korkmaya başlamışlar[dı]" (Soljenitsın, 2004, s.31). Öte yandan kamp idaresi, mahkûmlara asla karınlarını tam olarak doyurabilecekleri miktarda ekmek dağıtmamaktadır. Mahkûmlarsa, bir yolunu bulup yiyecek artırmaktadırlar: "Şapkasını çıkarıp içine iyice gizlediği iğnesini ipliğini çıkardı. Sonra ekmeği sakladiğı şiltenin deliğine dikiş atmaya başladı. Bu arada ă̆zındaki şeker de erimiş̧ti” (Soljenitsın, 2004, s.24).

Eserde bir leitmotiv olarak mahkûmların zihninde tekrarlanıp duran düşüncelerin önemli bir kısmında ekmek simgesi ortaya çıkmaktadır. Bilhassa idareden çeşitli yollarla saklanan ekmeklerin bulunabilmesi ihtimali, anlatıcı Şuhov'un aklını devamlı meşgul eder: "Şiltenin ucunu üstten yokladı, ekmek parçası içindeydi. Deliğin ağzın dikmekle iyi etmişti" (Soljenitsın, 2004, s.129). "Şuhov sol tarafinda, tam kalbinin üstünde sert bir şey hissetti. Bu, öğle yemeğine ayırdiğı, sabahleyin ikiye bölerek ceketinin cebine soktuğu ekmeğin bir parçasıydı" (Soljenitsın, 2004, s.44). Bu bağlamda, anlatıcı kahraman Şuhov'un zihninin, gün içinde defalarca, sakladığı ekmek tarafından rahatsız edildiği açıklık kazanmaktadır: "Bir hükümlünün düşünceleri de kendisi gibi kısıtlıydı, dönüp dolaşıp ayn şeylere geliyordu. Acaba şiltesine sakladığı ekmeği bulurlar mıydı?” (Soljenitsın, 2004, s.36).

"Ölenleri Hatırlamak: Varlam Şalamov'un 'Kolıma Hikâyeleri'nde Yineleme, Kimlik ve Tanıklık” (Recalling the Dead: Repetition, Identity, and the Witness in Varlam Shalamov's Kolymskie rasskazy) adlı çalışmasında Sarah J. Young, Soljenitsın gibi bir Gulag mahkûmu olan Rus yazar Varlam Şalamov'un kısa öykülerinde yinelemenin, eski kamp mahkûmlarının yeni yaşamlarına yansıyan travmanın bir göstergesi olarak nasıl işlev gördüğünden söz eder. Kamptan sağ çıkanların bellekle kurdukları sorunlu ilişki, sürekli tekrar edilen belirli imgelerin tekdüzeliğinde saklıdır. Bununla beraber yineleme, yazarın yaşadığı travmaya tanıklık edebilmesi ve onunla duygudaşlık kurabilmesi adına, 
“The Banality of Evil”: Reading Alexander Solzhenitsyn's Impressions of Soviet labor camps through Hannah Arendt's concepts / D. Özakın (p. 431-449)

okuyucuyu metne çekmenin bir yolu haline gelmiştir (Young, 2011, s.371). "Kolıma Hikâyeleri”nde üslup özelliklerine dikkat çeken Tetik, yazarın geçmişiyle ve okurla kurduğu bağ üzerine benzer bir yorumda bulunarak Şalamov'un "sırf okuyucu rahat bir ortamda acımasız kamp yaşamın yakından tanıyabilsin diye Stalin Döneminin kamplarında bizzat kendisinin yaşadığı dönemin actmasız şartlarmı, dönemi ve gerçekleri okuyucuya ve geleceğe aktarma misyonunu" yüklendiğini, bunu da leitmotiv ve yinelemelerin de aralarında yer aldığı söz sanatlarına başvurarak ve metnin fonetik ritmini ön plana çıkararak başardığını ifade eder (Tetik, 2019, s.235).

Eski bir kamp mahkûmu olarak Şalamov'la ortak bir kaderi paylaşan Soljenitsın'ın kahramanı Şuhov'un, kampta hayatta kalabilmenin simgelerinden biri haline gelen ekmekten sıklıkla söz etmesi, eserde leitmotivlerin bir anlatım tekniğinden daha fazlasını ifade etmek üzere kullanıldığını ortaya koymaktadır.

"Kahvaltısın soğuk ve ekmeksiz yediği için Şuhov şimdiden açlık hissediyordu. Midesinin kazınmasını duymamak, hep yiyecek düşünmemek için yakında eve yazacağı mektubu tasarlamaya başladı" (Soljenitsın, 2004, s.36) ve "Karnının gurultusunu dindirmek için, temiz beze sardığı ekmeği koynundan çıkard,, bezi önüne yaydı, ekmeğin tek kırıntısını bile düşürmemeye dikkat ederek ısıra ısıra yemeye başladı" (Soljenitsın, 2004, s.44)

cümlelerinde görüleceği gibi, Şuhov’un gününün büyük bölümü, açlı̆̆ını dindirmek, olası yiyecek sıkıntısı için kurallara aykırı bir biçimde ekmeği "zula etmek" ve günün geri kalanında yakalanma korkusu yaşamakla geçer. Şuhov ekmekten ve bir kap çorbadan öyle sık söz eder ki, kamp yaşamında artık soyut ve erişilmez bir ütopyaya dönüşen özgürlük idealinin yerini gündelik ihtiyaçların ve hayatta kalabilmek, günü kurtarabilmek mücadelesinin aldığı apaçık ortaya çıkar. Zira Şuhov’a göre artık "çalışma kampından mektup göndermek dipsiz kuyuya taş atmak gibiydi. Bütün yazdıklarm, seslenişlerin yok olup gidiyordu" (Soljenitsın, 2004, s.37). Böylelikle Şuhov, okuru geleceğe dair içine düştüğü umutsuzluğun ve ekmek simgesi etrafında dönüp duran, adeta kapana sıkışmış kısıtlı düşüncelerinin içine çekmektedir.

Şuhov'un aklına sık sık, köyünde yediği yemekler ve bolluk zamanları gelir. Oysa kamp yıllarında "bunun böyle olmaması gerektiğini" anlamıştır: "İnsan yemek yerken her lokmayı tadını çıkara çıkara çiğnemeliydi. Tipkı şimdiki gibi; ufak lokmaları diliyle damağında eze eze, bir avurdundan öbürüne döndüre döndüre... Şu yarı yartya hamur çavdar ekmeği ne kadar da lezzetli kokulu geliyordu insana!" (Soljenitsin, 2004, s.45).

Kamp düzeninde çalışma, cezalandırma ve ödüllendirme, tek bir şeyin etrafinda dönmektedir: Yaşamı sürdürebilmeyi temsilen, bir lokma ekmek. "Yani bunlarn yaşamlarma hükmeden işte bu 200 gramdır" (Soljenitsın, 2004, s.56). Ekmek ile birlikte, yemeği, ısınmayı ve karnını doyurmayı çağrıştıran diğer eylemler de, eserde leitmotiv olarak yinelenir: "Elini iç cebine sokup temiz beze sardığı ekmek kabuğunu çıkardı; kaşık gibi bükük ekmek sırtıyla çanağın dibini, kıvrık kenarlarını güzelce temizledi”" (Soljenitsin, 2004, s.72).

Hükümlülere sabah daha koyu, akşam daha sulu çorba verilir zira sabah çalışmaları gerekir, gece, nasıl olsa uyuyacaklardır. Şuhov, sıcak çorbasını kaşıklarken "Oh! Ne kadar hoştu! Hükümlünün dört gözle beklediği kısa ve çok zevkli bir andı bu!' (Soljenitsın, 2004, s.137) diye düşünmeye başlar. Bu kısa anlar, hükümlülerin kampa mahkum olduklarını unutmaya çalıştıkları kaçış dakikalarıdır. Ancak bir mahkûm açlı̆̆ını ancak bir öğün unutabilmekte, bedeni devamlı doyurulmak için onu çağırmaktadır: "Şu mide denen şey hayının tekiydi, bir gün önceki tokluğunu hiç anımsamazdı ama gelecek günler için durmadan, durmadan isterdi" (Soljenitsin, 2004, s.138). 
Mahkûmlar, temel yaşamsal ihtiyaçlarının yoksunluğu tarafından sınanırlar, günü geçirebilmek için girdikleri mücadelede, özgürlük gibi ihtiyaçları ikinci plana itilir. "Bütün sinirleri yay gibi gerilmişti. Şu sigaranın izmariti, onun için özgürlüğünden daha önemliydi” (Soljenitsın, 2004, s.28). Kamp gerçeğinin en çelişkili yönü de budur. Hükümlü, açlı̆̆ını dindirmek için, zihnindeki özgürlük düşüncesinden bile vazgeçmeye hazır, ilkel güdüleriyle hareket eden bir canlıya indirgenmiştir.

"Çalışmaktan dönen hükümlüler işte bu akşam sayımı sirasında en çok üşümüs, rüzgâr yemiş ve aç durumda olurlardı. İşte bu anda onlara verilecek bir çanak sıcak lahana çorbası kuru toprağa düşmüs yağmur serpintisi gibi vücutlarında dağglır giderdi. Bir çanak çorba hükümlülere geçmişteki ve gelecekteki yaşamından, özgürlüğünden daha değerliydi” (Soljenitsın, 2004, s.122).

Mahkûmiyetin devamlı uzatıldığı, kamptan ayrılma umudunun giderek azaldığı ve mahkûmların kendilerini bir kısır döngü üçünde hissettiği bu atmosferde, yemek yeme eylemiyle hissedilen kısa süreli mutluluklar, umutsuz mahkûmlar için, kendilerini normal insanlar gibi görebildikleri anları temsil eder:

“Şuhov önce çorbasının üstteki sulu bölümünden başladı içmeye. Üst üste, üst üste kaşıklıyordu... Sıcacık çorba karnına girip oradan bir haz dalgası biçiminde bütün bedenine yayıldı" (Soljenitsın, 2004, s.137).

"Suyu bol çorbanın sevinilecek tek yanı sıcak olmasıydı. Ama bu sefer Şuhov'un çorbası soğumuştu. Bununla birlikte sindire sindire yemeye koyuldu. Yer yerinden oynasa aceleciliğin gereği yoktu. Uyku saatlerini saymazsak kamp sürgünü kahvaltıda on, öğle ve akşam yemeklerinde de on beşer dakikayı canı istediğince harcardı" (Soljenitsın, 2004, s.17).

Soljenitsın trajik anılarını sakin, soğukkanlı bir dille kurgulamakta ve aktarmaktadır. Yazar, "kamp koşullarında insan kalabilmek mümkün mü?” sorusunu, gündeliğin sıradanlığı içerisinde sorar, yanıtları, çalışma kampında sürdürülen rutin yaşamın insanlık dışı yönlerinde arar. "Olsun, hükümlünün midesi buna da katlanır. Bu gün az yerse, yarn doyabilir. İşte bu tath hayalle yatan hükümlüler dört gözle bedel gününü beklerler" (Soljenitsın, 2004, s.78). Bu arayış, eserin sonlarına doğru Şuhov'un, hücreye ya da Sosyalist Yaşam Sitesi'ne gönderilmediği ve karnını doyurabildiği için

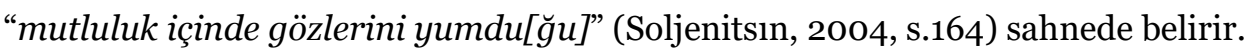

Kamp yaşamı, insanın biyolojik gereksinimlerini açığa çıkarır ve önceliği en temel ihtiyaçlara indirger. Kamp koşullarında, ihtiyaçlar hiyerarşisinin kültürel basamağına tırmanmak mümkün değildir; özgürlüğü hayal etmekse imkansızdır. "Çalş̧ırken ne kadar da çabuk geçiyordu zaman? Kampta günlerin böylesine çabuk geçmesi hep şaşırtırdı onu. Buna karşılık cezası bir türlü bitmiyor, sanki uzadıkça uzuyordu..." (Soljenitsın, 2004, s.60). Bu nedenle mahkûmlar, devamlı uzatılan ceza süreleri nedeniyle hiç erişemeyecekleri bir hayal gibi algılamaya başladıkları özgürlük düşüncesinden giderek uzaklaşmışlardır ve Şuhov artık "özgürlüğü kendisinin de isteyip istemediğini bilmemekte[dir]" (Soljenitsın, 2004, s.161).

Hannah Arendt, İkinci Dünya Savaşı sürecinde olağanüstü halin baskısıyla, Sovyetlerde polis terörünün bir süreliğine etkisini azaltmak zorunda kaldığını belirtir. Böylece rahat bir nefes alan halk, düşmanı yenilgiye uğratabilmiştir. Ancak "esir kamplarından ve işgal görevlerinden geri döndüklerinde derhal toplama kamplarına gönderildirler. Özgürlük alsşkanlıkların kaybetmeleriydi amaçlanan” (Arendt, 1997, s.105) sözleriyle, Şuhov ve mahkûm arkadaşlarının zihinlerine çekilen sınır çizgilerinin ardındaki olguları açıklı̆ga kavuşturur ve kampta özgürlüğün neden yitip giden bir ihtimale dönüştüğünü anlamamızı sağlar. Sovyet halkına kasıtlı olarak "özgürlük alışkanlığı" kaybettirilmiştir ve kamplar, bu amaca hizmet eden başlıca araç olarak işlev görmüştür. 
“The Banality of Evil”: Reading Alexander Solzhenitsyn's Impressions of Soviet labor camps through Hannah Arendt's concepts / D. Özakın (p. 431-449)

\section{“İvan Denisoviç’in Bir Günü’nde kötülüğün sıradanlığı}

Sovyet çalışma ve ıslah kampları, kültür kavramına yüklenen büyük anlam dizgesini sorgulatacak uygulamalara sahne olmuştur; mahkûmlar sosyal ilişkilerinden ve rollerinden koparılmış, eylemsiz birer organizmaya indirgenmiştir. Gulag mahkûmlarının giderek mekanikleşen hareketleri ve anlamsızlaşan günleri, kamp düzeni içinde, iktidarın bedeni nasıl kuşattığını ve yurttaşlarını işgücünden faydalanmak üzere kimliksiz bıraktığını açığa çıkarmaktadır. Bu kimliksizliği vurgulamak üzere, mahkûmlar isimleri yerine numaralar taşımaya başlamışlardır. Okur da kamptaki bir güne Ş-854 olarak anılan mahkûm İvan Denisoviç Şuhov'un bakış açısından tanıklık eder.

Mahkûmların yakalarındaki numaralar, isimleri yerine numaraları ile çağrılmalarını sağlar. Böylece onların bireyler değil, kamp düzenininin parçalarından ibaret kişiliksiz sürgünler oldukları sık sık kendilerine hatırlatılır. Numaralandırma, düzen ve itaat duygularını da perçinlemeyi hedefler:

"Y-kurk sekiz! Ellerini arkaya bağla! B-beş yüz iki! Hizaya gir!” (Soljenitsin, 2004, s.36).

“Ne o, Ş-854, harcı neden öyle ince koyuyorsun?” (Soljenitsin, 2004, s.95).

Distopik kurgularda da sıklıkla, topluluk sakinlerinin, bireysellikten uzaklaştırılmış uzamlarda, numaralandırılarak ya da kod adlarıyla bir araya getirilmeleri dikkat çekmektedir. Gulag sistemindeyse distopik tasarı, gerçeğe dönüşmüştür. Hükümlülerse "numaraların bir ağırhı̆̆ı olmadığına göre, taşıya taşıya sırtımız aşınmıyor ya!" (Soljenitsın, 2004: 64) diyerek durumu kabullenmeye başlamışlardır. Yine de numaların omuzlarına yüklediği sorumluluktan kaçmaları mümkün değildir: "Şu numaralar hükümlülerin baş belasıydı. Okunakh olursa muhafiz uzaktan bir kusurunu görüp not ederdi. Silik olursa 'Neden yeniletmedin?' diye çıkışır, adamı hücreye gönderirlerdi”' (Soljenitsın, 2004, s.27).

Numaralandırılarak kimliksiz kılınan beden, gündelik yaşamın en temel eyleyicisi olarak, hem kötülüğe maruz kalmakta, hem de kendi isteklerini temin edebilmek adına, iyiliğin varlığını unutmaktadır. Kampın tekdüzeliği gibi, beden de her gün doyurulmayı bekleyen, bitip tükenmeyen açlıklarını yineleyerek, sahibini kıskacına almaktadır. Kampta bedensel ihtiyaçlar, özgürlük gibi soyut kavramların ötesine geçmektedir. Her ne kadar, o özgürlüğün elde edilmesi, bedensel acıyı topyekun dindirecek olsa da, anlık ihtiyaçların giderilmesi mahkûmların yaşamında ağır basmaktadır. Örneğin Şuhov, köyünü ve aile ocağını anımsayarak "boş hayaller" kurması için bir nedeni kalmadığını düşünmektedir. Şuhov'un değişmeyen tek isteği, sebze çorbasını sıcak sıcak kaşıklamaktır. "Çünkü sebze çorbası soğuyunca hiçbir şeye benzemezdi” (Soljenitsın, 2004, s.125). Şuhov'un ailesine dair hayallerinin ardından sarf ettiği tek söz, anlık ihtiyaçlarına ilişkin ve daha ulaşılabilir olan şeye odaklanmıştır; sebze çorbasına. Kamp gerçeğinin en acı yönü de budur, “çıplak hayat” herkesi ümitsiz kılmıştır.

"Çıplak hayatın siyasallaştırılması, modernliğin belirleyici olgusunu" (Agamben, 2017, s.13) oluşturduğu için ve Gulag, Sovyet modernleşmesinin ve ekonomik kalkınmasının örnek mekânlarından birini teşkil ettiği için, kamp yaşamı, biyolojik çaresizliği eşit bir biçimde pay etmiştir. Zira Gulag sistemi, hem hükümlünün bedensel emeğinden bedava işgücü olarak faydalanmayı; hem de hükümlüyü çalıştırılmadığı zamanlarda- bedensel olarak zayıf düşürüp uysallaştırmayı hedefler. Kampta verilen yemek öyle yetersizdir ki Şuhov "en kötüsü de, çanaklardan yemek artıkların yalamamak için insanın sinirlerinin demirden olması gerekiyordu" (Soljenitsin, 2004, s.6) yorumunda bulunur. Bu sistem, mahkûmların elinden geleceğe dair kurtuluş beklentilerini almış ve onları gündelik hazların (ki bu "sözde keyifler" dondurucu soğuklarda gün boyu çalıştırıldıktan sonra, içinde sadece ufacık balık kırıntıları bulunan duru bir çorbayı biraz daha sıcak içebilmekle sınırlıdır) geçici mutluluğuna mahkûm 
etmiştir. Örneğin mahkûmlar tütün bulamadıkları zaman, sigara izmaritlerini tükürük hokkalarından çekip çıkarmaktadırlar (Soljenitsın, 2004, s.46). Kamp kanunları, entelektüel kavramlarla değil, gereksinimlerle işlemektedir ve bu ihtiyaçlar, gündelik iyiliğe ağır basmaktadır. Kamp tecrübesi, sert iklim ve ağır çalışma koşullarında, özgürlüğün olmadığı bir sistemde, hala insan kalabilmenin imkanlarını sorgulatmaktadır.

Arendt kötülüğün sıradanlığı (the banality of evil) anlayışıyla, kötülüğün yaratıcısı olan, yetkiyi elinde bulunduran ve sistemin işleyişinde önemli makamları işgal eden kişilerdeki itaatkârlığın bayağılığına da gönderme yapmaktadır. İyilik, hem "sıradan" (olağan) hem de "bayağı" olan tarafından ele geçirilmiştir. Kampta insalık suçlarının işlenmesine neden olan yetkililer, sadece görevlerini ifa etmek isteyen ve temel prensipleri itaat olan sıradan insanlardır. Kötülüğün kaynağı, onların eylemlerinin "fikirsiz" doğasında yatmaktadır.

Benzer biçimde, roman boyunca gerek yöneticiler, gerekse mahkûmlar, "fikirsizliği" seçmeye mecbur bırakılmışlardır. Yetkililer, Eichmann gibi sadakat göstermekte iken, mahkûmlar, başka çıkar yol olmadığı için itaat etmeye, gönüllü olmaya, rıza göstermeye başlamışlardır. İtaat, acılarını dindirmese de, azaltmaktadır. Hatta mahkûmlar, derin düşüncelere dalmalarını engellemesi bakımından, ne kadar şikayet ederlerse etsinler, ağır bir iş gününü dinlenmeye yeğlemektedirler. Kamp düzeni içerisinde, eğer "kendileri yapmazsa başkaları zaten yapacağı için" (Eichmann ve diğer savaş suçlularının sıklıkla yinelediği ifadelerde olduğu gibi) görevliler yemeğin fazlasını kendi paylarına ayırmakta, mahkûmlar birbirlerine iş yıkmaktadırlar. Kötülüğü belirleyen tek neden, uygun koşulların oluşmuş, insanların da kaidelere uygun hareket etmiş olmalarıdır. Kötülük, sıradan olanın içine nüfuz etmiştir. Aynı koşullar altında, bu koşullarla sınanmadığı için masumlar safında kalan pek çok insan, belki de aynı eylemlerde bulunacaktır.

“İvan Denisoviç’in Bir Günü”nde kötülüğün sıradanlığı, iki ana yoldan mahkûmları kuşatmaktadır. Birincisi, itaat zinciri içerisinde acımasızca emirler ve cezalar veren yetkililerin sıradanlığıdır. Onlar, sadece kuralları yerine getirmektedirler. Bu ana yola erişen bir patikayı ise, mahkûmların birbirlerine karşı işledikleri kötülükler oluşturur. Mahkûmlar arasında hırsızlar ve muhbirler de vardır, bu insanlar kendi çıarları için başkalarını feda etmekten çekinmezler.

Kötülüğün sıradanlığının ikinci dönemecinde ise, kötülüğün günlük hayatın bir parçası haline dönüşmesi ve sonsuzmuş gibi yinelenmesi teşkil eder. Kötülük öylesine yaygındır ki, artık beklendiği kadar zarara, tepkiye ve üzüntüye dahi yol açmamaktadır. Kötülük tarafından böylesine kuşatılmak, mahkûmları tepkisizleştirmiştir. Kötülük sonsuza dek belirsiz bir çerçevede çoğaldıkça, söz gelimi cezanın nedensizce uzatılabileceği dikkate alındığında, iyiliğin varlığına olan inancı da alıp götürmüştür. İvan Denisoviç, bir sarmalık tütünü özgürlükten daha kıymetli bulmaya başlamıştır. Özgürlüğüne kavuştuğunda ailesini nasıl geçindireceğini düşünemez olmuştur. Hatta cezası daha uzun olanların yanında özgürlüğü düşlemek dahi ayıp bir şey gibi geldiğinden, mahkûm arkadaşlarının yanında sevincini belli etmemek için olumsuz bir konuşma yapma gayreti içinde bulmuştur kendini: "Eski bir hükümlünün bu düşüncelerini açı̆̆a vurması başkalarını yanında hoş kaçmazdı" (Soljenitsın, 2004, s.62).

Kötülüğe karşı gösterilebilecek potansiyel direnç, kampta bir lokma ekmek yiyebilmek, yıkanıp temizlenebilmek, boynunu soğuktan koruyabilmek için verilen mücadele esnasında yitirilir. Kötülük, mahkûmları en basit ihtiyaçları çerçevesinde kuşatmış ve öğütmeye başlamıştır. Yazar “çıplak hayat” biyolojik zorunluluklarını ve mahkûmlar arasındaki dayanışma duygusunun ilkel dürtüler nedeniyle 
“The Banality of Evil”: Reading Alexander Solzhenitsyn's Impressions of Soviet labor camps through Hannah Arendt's concepts / D. Özakın (p. 431-449)

geri plana itilmesini tüm gerçekçiliğiyle ifade eder: "Şuhov kılçıklardan bah̆̆̆n pullarına varıncaya kadar her şeyini emerek gerisini masaya tükürüyordu. Bahğın kuyruğunu, solungaçlarm, gözlerini yerli yerinde görürse hiç birini burakmıyordu; ama çanağın içinde yüzen gözleri, ayr parçaları yemiyordu. Sonra insana ne derlerdi!" (Soljenitsın, 2004, s.17). Burada örneklenen gerçekçi anlatım tarzı nedeniyle Soljenitsın, bazı okurlarının olumsuz tepkisiyle karşlaş̧mıştır. "Bunun sebebi büyük ölçüde, yazarın, insanın ilkel, derin ve hayatta kalma-odaklı doğasımı açıça ortaya koyması olmuştur. Bu ilkel doğada tevekkül etmeye, asil özlemlere, soylu duygulara yer yoktur. Böylelikle yazar, başta sosyalist gerçekçilik olmak üzere birçok edebiyat kanonunu ihlal etmiştir" (Kozlov, 2011, s.194-195).

Kamp düzeni içinde tembelliği engellemeye yönelik otokontrol sistemi, cezanın da, ödülün de kolektif niteliği sayesinde temin edilmektedir. Ĕger günlük olarak tamamlanması gereken görevlerde bir aksama meydana gelirse, bundan o iş kolundaki tüm mahkûmlar sorumlu tutulmaktadır. "Burada hükümlüleri çalışmaya başlarındaki adamlar değil, kendileri zorlarlar. Bunun işleme tarız da şöyledir: Ya hepsine fazladan bir şey verilecekti, ya da hepsi oturup acindan geberecekti" (Soljenitsın, 2004, s.54). Bu nedenle kimse işi aksatmayı aklının ucundan bile geçirmemekte, herkes, Arendt'in "normal olanın içindeki vahşeti” göstermek üzere vurguladığı gibi "sadece görevini yerine getirmektedir”. Zira verilen cezalar "yasalar çerçevesinde" belirlenmektedir. Bir süreliğine sistemin şimdiki ihtiyaçlarını karşılayan yeni bir yasa icat edilmekte, eski kanunlar geçerliliğini yitirmekte ya da içeriği, insanlara verilmek istenen cezaya uydurulmaktadır. Kamp sisteminin devamlılı̆̆ının sağlanması adına vatandaşlıktan doğan haklar yok sayılmakta ve vatandaşlık tanımı da, suçlar gibi muğlak bırakılmaktadır. Şuhov'un not ettiği gibi kamptan "tek kurtuluş yolu durmadan çalışmaktı" (Soljenitsın, 2004, s.7)

\section{Sonuç ve değerlendirme}

Gulag infaz sistemini Nazi kamplarından ayıran en belirgin fark, Sovyet çalışma kamplarının kurulmasındaki asıl amacın imha olmaması, kampın işleme mantığının mahkûmların emeğinden azami ölçüde faydalanılması fikrine dayanmasıdır (Belova, 2013, s.64). Bu nedenle, Nazizmin ve Stalinizmin kamp düzeneğini karşlaştıran Arendt, "Rusya'da, Nazi Almanyası’nda olduğu gibi düpedüz korkunç ve çürütülemez kantlarla belgelenebilecek bir hikâyeden veya hikâye sonlarından söz edilebilecek şeyler yaşanmad,, yakın gelecekte yaşanması da muhtemel görünmüyor" (Arendt, 2014, s.12) ifadelerini kullanmıştır. Arendt'e göre, Sovyet kamplarına ilişkin detaylı bilgi ve belgelerin henüz ortaya çıkarılmadığı dönemde Gulag, Nazi vahşetinin yaşandığı kamplarla kıyaslanamaz.

"Yirmilerin ve otuzlarm Rusyası'yla ilgili bir tasvirde hemen öne çlkan ve bugün de yaygm olan ayyaşlık ve kabiliyetsizlik Nazi Almanyasının hikâyesinde belirli bir rol oynamamışken, Alman toplama ve imha kamplarında yaşanan tarifsiz vahşete de, mahkûmların işkenceden çok ihmalden öldüğü Rus kamplarında pek rastlanmamıştır" (Arendt, 2014, s.16).

Ancak geçen zamanla beraber, sadece kampa mahkûm edilen edebiyatçlların, bir zamanlar yasaklı olan eserlerinin dünya okuruyla buluşması sonucunda değil; aynı zamanda, doğrudan Gulag sistemine ilişkin belgelerin de yayımlanmasıyla, Sovyet kamplarının farklı nitelikleri gün yüzüne çlkmıştır. Arendt bu gelişmelere ilişkin totaliter rejimlerle ve yeni diktatörlüklerle ilgili araştırmalarda olağanüstü bir artış yaşandığını belirtir ve ekler: "Mevcut Rus yöneticilerin ikiyüzlülüğünden dolayı genç nesilden Rus entelektüeller şu anda isyan bayrağı açtılar. Zira insanların kitlesel olarak tasfiye, tehcir ve yok edildiklerinin bilinmesinin zamanı geldi" (Arendt, 2014, s.19). 
20. yüzyllın etkin düşünürlerinden Yahudi asıllı Hannah Arendt, Yahudi soykırımında aktif rol oynamaktan sorumlu tutulan Nazi subayı Adolf Eichmann'ın 1960 yılında Kudüs'te görülen davasını, The New Yorker muhabiri olarak kaleme alıncaya dek, kötülüğü radikal bir problem olarak tanımlama eğilimindedir. Ancak Eichmann duruşmasının ardından, karşısında insanların kitlesel kıyımından sorumlu bir "canavar" bulmayı bekleyen Arendt, gördükleri karşısında şaşkınlığa düşmüştür. Eichmann, sadece kanun tarafindan belirlenen yükümlülüklerini yerine getirmeye ve terfi etmeye çalışan sıradan bir memurdan başka bir şey değildir. Arendt bu çelişkiyi "kötülüğün sıradanlığı" kavramsallaştırmasıyla açıklamaya çalışır. Zira Eichmann, kötülük eylemini "fikirsizce" gerçekleştirmiş, koşullar öyle gerektirdiği için, devletine duyduğu sadakatle, görevine sıkı sıkıya bağlanmıştır. İşte kötülüğün bu "normal" doğası; tamamen dönemsel koşulların uygun gördüğü yasal bir çerçeveye dayanıyor olması, üstelik faaliyetlerin ülkeye "faydalı" olacağına duyulan inanç, durumu daha korkunç kılmaktadır.

Bu çalışmada, Sovyetler Birliği’nde ekonomik gelişmenin ana damarlarından biri olması ümidiyle mahkûmların bedensel işgücünden fayda sağlanabileceği fikrinin hayata geçirildiği ${ }^{5}$ Sovyet 1 slah ve çalışma kamplarında (Gulag) "kötülüğün sıradanlığı"nın çeşitli görünümleri ele alınmıştır. Sovyet kampları "kötülüğün" olağan bir biçimde ortaya çıkmaya eğilimli doğasına uygun bir mekân oluşturmuştur. Zira çalışma kamplarının asıl amacı, devletin ekonomik büyümesini desteklemek olarak açıklanmıştır; ancak zaman, bu amaç uğruna ödenen bedelleri açığa çıkarır ve kampın insanlık dışı uygulamalara sahne olduğunu ortaya koyar. Arendt, Soljenitsın'ın "Stalin yöntemlerinin rasyonel iktisadi kalkınmayı nasıl harap ettiğini somut ayrıntılarla gösterdiğini” belirtir (Arendt, 1997, s.105).

Çalışmada, Aleksandr Soljenitsın’ın “İvan Denisoviç’in Bir Günü” adlı eserinde kötülüğün sıradanlığının, iki ana yoldan mahkûmları kuşatmakta olduğu sonucuna erişilmiştir. Bu yollardan birincisi, itaat zinciri içerisinde acımasızca emirler ve cezalar veren yetkililerin sıradanlığıdır. Arendt'e göre asıl sorun, bu yetkililerin ne sapık ne de sadist olmasından kaynaklanır; sorun, onların "dehşet verici biçimde normal" olmasında yatmaktadır (Arendt, 2009, s.281). Onlar, sadece kuralları yerine getirdiklerine inanırlar, üstelik bu eylemleri Sovyet yasalarına uygun olarak, devlet lehine ve ekonomik kalkınma adına hararetle savunurlar. Yasalara uygunluk problemi ve yurttaşlıktan doğan haklar tanımının totaliter rejimdeki dönüşümü, çalışmanın ceza kanununun 58. maddesine ilişkin bölümünde tartışılmıştır. Hukuk kurumları, yargılama usulleri ve ahlaki standartlar açısından "normal" sayılan bu uygulamalar, Arendt düşüncesinde "yapılan bütün kötülüklerin toplamından daha dehşet verici"dir (Arendt, 2009, s.281).

Mahkûmları olağan kötülükle sarmalayan ana yola erişen bir diğer patikayı, mahkûmların birbirlerine karşı işledikleri kötülükler oluşturur. Mahkûmlar arasında hırsızlar ve muhbirler de vardır, bu insanlar kendi çıkarları için başkalarını feda etmekten çekinmezler.

Kötülüğün sıradanlığının ikinci dönemecinde ise, kötülüŭün günlük hayatın bir parçası haline dönüşmesi ve sonsuzmuş gibi yinelenmesi karşımıza çıkar. Bu kısırdöngü eserin kapanış pasajında “Kalk vuruşundan yat vuruşuna kadar Şuhov’un böyle tam üç bin altı yüz elli üç günü geçmişti, daha

Bu fikrin hayata geçirilmesi, kamplarda yaşanan insan hakları ihlallerine rağmen ekonomik karşıllı̆ını bulmuş ve "teknik anlamda" başarılı olmuştur. Khairmukhanmedov bu gerçeği "Nazi Almanya'sı ile Stalin Rusya'sı arasındaki benzer noktalar totaliter rejimlerin ortak özelliklerini saptamamıza imkân sağhyor. İkisi de insan değil akh merkeze alan modern devletler idi. İkisinde de modern akıl gerçeklere boyun eğiyordu. (...) GULAG'n faaliyetleri sonucunda, XX. asrın en parlak sanayi yapıları ortaya çıtı. Hem rejim düşmanların etkisiz hale getirerek, hem onların bedava işgücünü rasyonel bir şekilde, kullanarak Stalin dönemindeki Sovyet sanayi devrimi gerçekleşti” (2007, s.171) tespitiyle ortaya koyar. 
“The Banality of Evil”: Reading Alexander Solzhenitsyn's Impressions of Soviet labor camps through Hannah Arendt's concepts / D. Özakın (p. 431-449)

da geçecekti” (Soljenitsın, 2004: 164) ifadelerine yansır. Şuhov, Şubat ayının 29 çektiği yılları da hesaba katarak ekler: "Sondaki üç gün ise, artık yzllardan (1) eklenenlerdi" (Soljenitsın, 2004, s.164).

Eserin kapanış cümlesinde de görüleceği üzere, tüm detaylarıyla anlatılan günün tekdüzeliği ve tekrarlanacak daha binlerce günden biri olması, kamp yaşamındaki umutsuzluğu belirleyen temel etkendir. Hüküm süresinin mahkûmlarda yarattığı olumsuz ruh hali vurgulanırken ekmek, soğuk, isimler yerine numaralarla çağrılmak, bir lokma yemek yiyebilmek, ısınmak, yıkanabilmek için fırsat kollamak gibi nesne ve eylemler leitmotiv olarak yinelenir ve kamp yaşamı içinde, hayata bağlllık, hayattan beklentisizilik, mahkûmiyetten kurtulma isteği gibi sembolik anlamlar taşır. Soljenitsın bu eseriyle, "kamp koşullarında insan kalabilmek mümkün mü?” sorusunu sorar. Yazar, kamp yaşamının, insanın biyolojik varoluşunu açığa çıkardığını, mahkûmları, "çıplak hayat”la baş başa bıraktığını ve önceliği en temel ihtiyaçlara indirgediğini bedenin gereksinimlerine ilişkin kavramların tekrarlanmasıyla açıklar. Bu koşullarda beden, sosyal kimliğin taşıyıcısı olmaktan ziyade bir corpus (özne olarak değil; cisim olarak beden) biçiminde tanımlanmış ve kısıtlanmıştır.

\section{Kaynakça}

Agamben, G. (2017). Kutsal İnsan: Egemen İktidar ve Çıplak Hayat. (Çev. İsmail Türkmen). İstanbul: Ayrintı.

Applebaum, A. (2006). GULAG: Pautina Bol'şogo terrora. Moskva: Moskovskaya şkola politiçeskih issledovaniy.

Arendt, H. (1997). Şiddet Üzerine. (Çev. Bülent Peker). İstanbul: İletişim.

Arendt, H. (2009). Kötülüğün Stradanlı̆̆: Adolf Eichmann Kudüs’te. (Çev. Özge Çelik). İstanbul: Metis.

Arendt, H. (2014). Totalitarizmin Kaynakları 3: Totalitarizm. (Çev. İsmail Serin). İstanbul: İletişim.

Belova, N. A. (2013). Istoriya GULAGa v sovremennoy istoriografii. Vestnik instituta: prestupleniye, nakazaniye, ispravleniye, 2 (22), 64-70.

Can, B. (2010). Aleksandr Soljenitsın’n Eserlerinde Şahıs Kadrosu. (Yayımlanmamış yüksek lisans tezi). Erciyes Üniversitesi Sosyal Bilimler Enstitüsü, Kayseri.

Ceylan, Ü. (2015). F. M. Dostoyevski’nin Ölüler Evinden Anılar ve A. İ. Soljenitsın’n İvan Denisoviç̧in Bir Günü Adlh Eserlerinde Gerçekçilik. (Yayımlanmamış yüksek lisans tezi). Gazi Üniversitesi Sosyal Bilimler Enstitüsü, Ankara.

Çelik, R. \& Can, B. (2010). Tarih-Edebiyat Bağlamında A. Soljenitsın'ın Eserlerinde Figürler. Erciyes Üniversitesi Sosyal Bilimler Enstitüsü Dergisi, 29(2), 271-282.

Çelik, R. (2018). Rusya Tarihinde ve Edebiyatında 'Sibirya'ya Genel Bakış. Nadir İlhan (Ed.), 4. Uluslararası Filoloji Sempozyumu Tam Metin Kitabı içinde (15-20. ss.). Elazı̆̆: Asos.

Erdem, H. H. (2010). Hannah Arendt’in Eichmann Davası Üzerine Düşünceleri. (flsf) Felsefe ve Sosyal Bilimler Dergisi, 9, 1-16.

Gürsoy, Y. (2018). Sovyet Dönemi Rus Edebiyat (1953-1991). Iksad Publishing House (e-kitap). https://www.iksad.net/product-page/sovyet-d\%C3\%B6nemi-rus-edebiyat\%C4\%B1-1953-1991 (Erişim: 21.03.2019).

Hobsbawm, E. (1996). Kısa 20. Yüzyıl (1914-1991) Aşırılıklar Çağı. (Çev. Yavuz Alogan). İstanbul: Sarmal.

Hosking, G. (2011). Rusya ve Ruslar: Erken Dönemden 21. Yüzyıla. (Çev. Kezban Acar). İstanbul: İletişim.

İnanır, E. (2018). Rus Edebiyatında Bir Topos Olarak Sibirya. Tobider International Journal of Social Sciences, 2(2), 64-73. 
Kaşoğlu, A. (2015). Kamp Gerçeğinden Edebiyata: İlk Çember, İvan Denisoviç’in Bir Günü, Gulag Takımadaları. Cemal Sakallı (Ed.), V. Uluslararası Karşılaştırmah Edebiyat Bilimi Kongresi Bildiriler Kitabı (Yerel Bağlamlar Küresel Yakınlıklar) içinde (400-409. ss.). Mersin: Mersin Üniversitesi Yayınları.

Khairmukhanmedov, N. (2007). Stalin Dönemindeki Siyasi Muhalifleri Tasfiye Uygulamaları ve Çalıştırma Kampları. bilig, 41, 155-174.

Kozlov, D. (2011). Otzıvı sovetskih çitateley 1960-h gg. na povest' A. I. Soljenitsına 'Odin den' Ivana Denisoviça': svidetel'stva iz arhiva 'Novogo mira' (çast' II). Noveyşaya istoriya Rossii / Modern history of Russia, 2, 192-200.

Kragh, M. (2014). Free and Forced Labor in the Soviet Economy: An Uncertain Boundary. Julie Hansen \& Andrei Rogachevskii (Eds.) Punishment as a Crime? Perspectives on Prison Experience in Russian Culture (43-65. pp.). Uppsala, Sweden: Uppsala University Press.

Lewin, M. (2016). Sovyet Yüzyıl. (Çev. Renan Akman). İstanbul: İletişim.

Malışev, A. M. (2010). Kontseptsiya totalitarizma v tvorçestve Hannı Arendt. Nauçnıy yejegodnik Instituta filosofii i prava Ural'skogo otdeleniya Rossiyskoy akademii nauk, 10, 297-328.

Netz, R. (2004). Barbed Wire: An Ecology of Modernity. Middletown, CT: Wesleyan University Press.

Sokolova, R.A. (2013). Tema Gulaga v tvorçestve M. M. Prişvina i A. I. Soljenitsına. Vestnik Ryazanskogo gosudarstvennogo universiteta im. S.A. Yesenina, 3 (40), 1-11.

Soljenitsın, A. İ. (2004). İvan Denisoviç̧in Bir Günü. (Çev. Mehmet Özgül). İstanbul: Cem.

Soljenitsın, A. İ. (2006). Arhipelag GULAG (1918-1956). Opt hudojestvennogo issledovaniya (III-IV). Yekaterinburg: Izdatel'stvo U-Faktoriya.

Şahinkaya, N. (2013). Aleksandr Soljenitsın'ın 'İvan Denisoviç̋in Bir Günü' ve 'Kanser Koğuşu' Eserlerinde Kişilik Çatışması. (Yayınlanmamış yüksek lisans tezi). Gazi Üniversitesi Sosyal Bilimler Enstitüsü, Ankara.

Tetik, K. (2019). Siirsel Düzyazı ve Varlam Tihonoviç Şalamov'un 'Kolıma Hikâyeleri’nden 'Kar Boyunca' Hikâyesi Örneğinde Şiirsel Düzyazının Üslup Özellikleri. Emine İnanır vd. (Ed.), Siyasi, Sosyal ve Kültürel Yönleriyle Türkiye ve Rusya içinde (227-239. ss.). Ankara: Berikan.

Ugolovniy Kodeks RSFSR. (1950). [Rusya Sovyet Federatif Sosyalist Cumhuriyeti Ceza Kanunu] Ofitsial'nuy tekst $s$ izmeneniyami na 1 iyulya $1950 \mathrm{~g}$. $i$ s prilojeniyem postateynosistematizirovannı materialov. Moskva: Gosudarstvennoye izdatel'stvo yurıdiçeskoy literaturı. http://istmat.info/files/uploads/49552/ugolovnyy_kodeks_rsfsr_-_1950.pdf (Erişim: 21.03.2019).

Yılmaz, S. (2018). Modern Yurttaşlı̆̆ın İstisnaları: Hannah Arendt ve Giorgio Agamben’in Görüşleri Çerçevesinde İnsan Haklarının Eleştirisinde Mülteciler ve Kamplar. Ankara Üniversitesi SBF Dergisi, 73 (3), $763-786$.

Young, S. J. (2011). Recalling the Dead: Repetition, Identity, and the Witness in Varlam Shalamov's 'Kolymskie rasskazy'. Slavic Review, 70 (02), 353-372. 